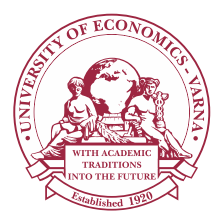

Izvestiya Journal of Varna University of Economics 3 (2021)

IZVEST IYA

Journal of Varna University of Economics

http://journal.ue-varna.bg

\title{
EFFECT OF RISK MITIGATION ON PROFITABILITY OF INSURANCE INDUSTRIES IN NIGERIA
}

\section{Kehinde Isiaq OLAIYA ${ }^{1}$, Kareem Abidemi ARIKEWUYO², Ashim Babatunde SHOGUNRO ${ }^{3}$, Lateef Adewale YUNUSA ${ }^{4}$}

${ }^{1}$ Department of Banking and Finance, Faculty of Administration and Management Sciences, Olabisi Onabanjo University, Ago-Iwoye, Ogun state, Nigeria, Email: kenkenolaiya@gmail.com

2 Department of Business Administration, Faculty of Social and Management Sciences, Southwestern University, Okun - Owa, Nigeria, Email: kareem.arikewuyo@yahoo.com

3 Department of Actuarial science and Insurance, Faculty of Management Science, University of Lagos, Email: amudasogunro@yahoo.com

${ }^{4}$ Department of Banking and Finance, Faculty of Administration and Management Sciences, Olabisi Onabanjo University, Ago-Iwoye, Email: yunusalateef@gmail.com

JEL: E59, M41

Key words:

Cost-minimization, Insurance-companies, Monitoring Profitability, Risk-management

\begin{abstract}
Risk management plays a critical part in every organization's profit maximization through risk cost minimization for wise protection, which cannot be overstated. Risk mitigation (rmt), risk monitoring $(\mathrm{rmn})$, risk management environment, procedure, and policies (epp), and risk measurement (rme) in relation to the profitability of the insurance industry in Nigeria were randomly selected from a wellstructured 5-point Likert scale questionnaire ranging from ' 5 strongly agree' to '4 agree', '3 undecided' to ' 1 strongly disagree'. Using the StataSE 14 statistical software, one hundred and twenty (120) questionnaires were recovered from respondents, accounting for 83 percent of the total questionnaires sent using the multiple regression statistical methodology. Risk reduction and risk monitoring have a considerable impact on the profitability of insurance companies in Nigeria, according to the findings. As a result, it concluded that risk mitigation and monitoring are important factors in determining industry profitability, and those insurance regulators should work to ensure that risk identification, assessment, measurement, and control mechanisms are implemented in accordance with best global practices in order to avoid financial crises and improve insurance performance.
\end{abstract}

(C) 2021 University of Economics - Varna

Citation: OLAIYA, Kehinde I., ARIKEWUYO, Kareem A., SHOGUNRO, Ashim B., YUNUSA, Lateef A. (2021) Effect of Risk Mitigation on Profitability of Insurance Industries in Nigeria. Izvestiya Journal of Varna University of Economics, 65 (3), pp. 330 - 343.

DOI: 10.36997/IJUEV2021.65.3.330 
Kehinde I. Olaiya, Kareem A. Arikewuyo, Ashim B. Shogunro, Lateef A. Yunusa.

Effect of Risk Mitigation on Profitability of Insurance Industries in Nigeria

\section{INTRODUCTION}

The quest for security is the ultimate concern of the individual, household, government, and business organizations. In today's challenging business environment, the world is currently facing several devastating effects of the Corona virus pandemic (COVID-19) and other risks that compounded man's living standard and well-being of some countries in Africa such as heightened costs of insecurity, political instability, growing unemployment rate, banditry, cybercrime, terrorism and stress (Epron, 2019; Yaya, Otu \& Labonte, 2020). These made the Nigerian government through its agencies create greater responsibility to individual and business organizations so that they can make economic decisions and find their own economic security (Sebastian \& DuruUremadu, 2017). As a result of insecurity the Nigerian business environment makes profits and losses become an acid test for individual and business performance and also there are other risks facing business organizations that might affect them to attain their set objectives of making a profit. Planning and carrying out business is increasingly becoming complex as businesses are faced with inherent risk which becomes the responsibility of another institution called insurance companies to manage.

Insurance companies are saddled with the responsibility of managing the risk of other businesses and are faced with their own inherent risk. They manage both internal and external risks in such a way that any failure in any of these may spell the doom of the goal which the insurance companies need to achieve. Yet, the complexity of the insurance business and its ability to manage business loss promotes the emergence of risks that must be considered in making a decision. These companies write policies that deal with specific risks, and in many cases, even underwrite exotic risks. In carrying out its core functions like pricing, underwriting, claims handling and reinsurance management, an insurer will also face a wide range of risks that are often interlinked and if not properly managed, could threaten the ability of the institution to make a profit and sustain it.

The phrase "risk" simply refers to the possibility of financial loss, which can be stated as a probability. It is a probability event that can have a good (opportunity) or negative (hazards) impact on companies (Ennouri, 2013). From an insurance standpoint, risk is multi-dimensional since they assume many sorts of business-specific risks that affect the organization's performance and profit motivation, and could finally bring the firm to a halt if not properly managed (Joosub, 2006; Fali et al, 2020). The problems must be appropriately identified and analyzed in order to minimize their negative impact on the fiduciary's profit maximization and financial performance.

Profitability is a critical component that keeps a company running and gives it a competitive advantage over its competitors, since it is crucial to all stakeholders 
- investors, stakeholders, and the economy as a whole. So far, investors are only concerned with the returns on their investments. Profitable businesses are economically and socially responsible because they create value, employ people, innovate, and pay taxes (Odusanya, Yinusa \& Ilo, 2018). An insurer faces numerous sorts of risk when carrying out these operations, which must be controlled by incorporating a robust risk management strategy into their system so that they can perform better.

Despite its obvious failure in the recent financial crisis, which originated in the United States and had a multiplier effect on the global market, risk management remains high on the agenda of insurance practitioners, academics, and corporate leaders (Huber \& Scheytt, 2013; Dabari \& Saidiu, 2014). Every insurable risk is covered by the insurance business, which is being superseded by the risk management concept. This coverage includes lowering the cost of pure risk, which is defined as a likelihood of occurrence that could result in financial loss (Sathyamoorthi et al, 2020; Arif \& Showket, 2015).

Risk management is important not only for insurance businesses' survival and profitability, but also for the worldwide market's growth and development (Chipa \& Womiori, 2017; Maher \& Anderson, 1999). It also provides for the transfer of loss to a third party in the event of a disaster, therefore risk management must be at the heart of an organization's operations in order to integrate risk management techniques, policies, and processes into the insurance business environment (Owolabi et al, 2017).

Business organizations and their management must adhere to policies and procedures that have been developed, agreed upon, and implemented. It indicates that an organization's rules and procedures will serve as a foundation for determining how to go from its current condition to a desired state. Failure to adhere to the established plan and rules, on the other hand, frequently leads to a systemic problem that overshadows the relevance of risk management techniques and limits the ability of businesses to profit and perform better (Tularam \& Attili, 2012; Amadei, 2016).

There is a need to assess if risk management standards are sufficient to avert difficulties, as seen by the recent crisis, which revealed that certain insurance companies suffered setbacks while others were bailed out by the government (Laeven \& Perotti, 2010). The purpose of financial institution regulators developing these regulations, such as the banking sector (Basel) and the solvency directive for insurance businesses, is to protect consumers and the insurance business from insolvency (Solvency II directive, 2009). Despite the fact that numerous studies have shown that risk management can reduce the impact of losses on profit maximization and insurance industry performance (Al-Nimer et al, 2021; Zhara \& Mazrek, 2014; Owojori et al, 2011; Schmit \& Roth, 1990), and despite the complexity of risk management processes in Nigeria, few studies have been conducted, and those that have been conducted have failed to achieve their 
Kehinde I. Olaiya, Kareem A. Arikewuyo, Ashim B. Shogunro, Lateef A. Yunusa.

Effect of Risk Mitigation on Profitability of Insurance Industries in Nigeria

objectives (Al-Nimer et al). As a result, the goal of this research is to see how risk reduction affects the insurance industry's profitability in Nigeria.

There are five sections to this paper. The first portion introduces the topic, while the second provides a literature review. Section three discusses the research methodology used, part four discusses the research findings, and section five finishes the report with the study's recommendation.

\section{LITERATURE REVIEW}

Risk management, defined as "the act of discovering, analyzing, assessing, monitoring, controlling, or minimizing risks that might lead to profit maximization and financial performance of an organization" (Abideen \& Saleem, 2011), is critical to an industry's sustainability. Risk management aids in the reduction, monitoring, and control of the likelihood of bad events, as well as the realization of opportunities arising from risk exposure resulting from an unexpected outcome and use of available resources (Wenk, 2005).

Because all of an organization, including insurance companies, involve risk, it is important to note that in the process of mitigating risk, it is necessary to communicate and consult with interested parties, monitor and analyze risk, and implement measures to ensure that additional treatment is not required (Risk Management ISO, 2009). Risk management encompasses all processes to include not just risks connected with potential and accidental losses, but also operational, reputational, financial, cyber, credit, underwriting, and market risks that could prevent a company from meeting its objectives. For better performance and profitability, these risk management components are critical in every firm (Gatzert, Schmit \& Kolb, 2016; Banks, 2008).

Many firms are now realizing that risks must be managed rather than avoided because they are an unavoidable part of doing business. Risks lead to opportunity, which leads to value, which leads to money for shareholders. Effective risk management can help to create shareholder value by attracting money and increasing returns through value-based management (Thornton, 2004). As a result, insurance businesses must employ good and high-quality measures in order to properly control operational risk.

Existing research has demonstrated the importance of risk management in the survival of enterprises, which organizations cannot overlook in order to accomplish their stated goal of improved performance. In their study, Zhara and Mazreku (2014) noted that successful insurance businesses have demonstrated that risk management not only preserves and grows wealth, but also enhances reputation regardless of scope and risk - inherent circumstances, while also providing opportunities and guidance against unforeseen contingencies. 
When compared to competitors who ignore risk management, Mohammed and Knapkova (2016) believe that insurance businesses with a competent risk management strategy have a higher return on equity and superior performance in key business indicators. Furthermore, according to Ebenezer and Omar (2016), financial institutions around the world have demonstrated that risk management is critical for firms that want to maintain their financial sustainability and operational service efficiency. They discovered that inadequate risk management and large redundancy frequently lead to failure and low profit margins (Ebenezer \& Omar 2016).

Similarly, Olalere, Ahmed, and Omar (2015) found that including risk management into corporate planning and performance management improves strategic and operational goals. Some insurance companies have been reported to not recognize the necessity of independent risk assessment units, instead relying on internal audit units for risk assessment and underwriting, which has resulted in conflicts of interest and inadequate risk management. As a result, Akotey \& Abor (2011) stressed the importance of establishing a risk management unit as a separate company in order to improve profitability and performance.

In addition, using a descriptive survey method, Owolabi et al (2017) analyze the influence of risk management on the profitability of insurance businesses in Nigeria. A total of 60 respondents were chosen using simple random sample techniques, and research analysis was conducted. The findings of the study demonstrated that financial risk management strategies have an impact on an insurance company's profitability.

With a sample size of 19 enterprises, Fali, Nyor, and Mustapha (2020) explore the impact of insurance specific risks on profitability in Nigeria during a 10-year period (2009-2018), using secondary data obtained from an annual reports. Three independent variables: re-insurance, technical provisions and underwriting risks were utilized as a measure of insurance specific risk, while net profit margin was used as dependent variable to measure the profitability of the companies. According to the findings, an increase in technological provision and risk underwriting resulted in low profitability for Nigerian insurance businesses, while the re-insurance risk had a negative and minor influence.

Chipa and Womiori (2017) in their study analyze the effects of risk management on insurance company's financial performance utilizing insurance firms based in Mombasa County Kenya and Directors, Managers or Head of Departments, personnel and Agents of insurance firms situated in Mombasa County. The study used a descriptive research methodology with a population of 150 respondents. Observation, questionnaires, and interviews were used to gather information. The study's findings indicate that independent variables such as liquidity risk management, operational risk management, and enterprise risk management have a substantial impact on insurance 
Kehinde I. Olaiya, Kareem A. Arikewuyo, Ashim B. Shogunro, Lateef A. Yunusa.

Effect of Risk Mitigation on Profitability of Insurance Industries in Nigeria

companies' financial performance in Kenya.

Ahmed (2016) used secondary data from the 2012 Nigerian Stock Exchange Fact Book to investigate the impact of capital size on insurance company profitability in Nigeria. The influence of capital size on profitability was estimated using a correlation research methodology and a Panel regression model (random effect). The study's findings revealed that capital size and gross premium have a beneficial but minor impact on the profitability of Nigerian insurance companies.

When assessing the impact of internal and external factors on life insurance business profitability in Pakistan, Rashid and Kemal (2018) look at three measures of insurer profitability: overall profit (ROA), underwriting profit (UP), and investment income (INI). The panel data regression method is used to examine data from 2006 to 2016. The outcomes of the study show that gross written premium, management costs, size, and interest rate all have a significant impact on the profitability of insurance companies. Life insurance firms' underwriting losses, according to the data, demonstrate the need for an improved underwriting system.

Kripa and Ajasllari (2016) examine the effects of growth rate, liabilities, liquidity, fixed assets, capital volume, and business size on insurance business profitability using annual reports from seven (7) non-life and life insurance businesses from 2008 to 2013. The findings of their research suggest that growth rate, liabilities, liquidity, and fixed assets are the most important factors affecting insurer profitability, indicating that growth rate is positively correlated with profitability, whereas liabilities, liquidity, and fixed assets are negatively correlated. Insurance company profitability is favorably connected with company size and capital volume, but their impact is statistically negligible.

Alsallawi (2018) investigated the impact of institutional variables such as leverage, capital market assets, and firm size on profitability risk, as well as the considerable impact of institutional theory on profitability risk among Saudi insurance businesses listed on the Saudi Stock Exchange (Tadawul). The study found that institutional factors have a significant relationship with the return on assets of Saudi insurance companies, which increased their profitability and provided significant directions for developing a profitable strategy among the companies, using multiple regression analysis on the data obtained.

\section{METHODOLOGY}

\subsection{Data}

To improve the accuracy of the study, information from respondents' relative perceptions on the Nigerian insurance business was gathered utilizing a survey design. 
The population of the study includes all 59 insurance businesses in Nigeria (www. naicom.gov.ng), with a sample size of $60 \%$ of the total population of insurance companies in Nigeria (36 insurance firms based and operating in Lagos state, Nigeria) chosen at random. Due to the nature of this study, 144 respondents were chosen at random from four compliance unit heads, including Audit \& Control, Risk Management, and Accounting \& Finance Departments.

A 5-point Likert scale well-structured questionnaire ranging from ' 5 strongly agree', ' 4 agree', ' 3 undecided' ' 2 disagree' to ' 1 strongly disagree' which provides response to variables such as risk mitigation $(r m t)$, risk monitoring $(r m n)$, risk management environment, procedure, and policies (epp) and, risk measurement ( $r m e)$ in relation to profitability of insurance industry in Nigeria were randomly distributed to the respondents. StataSE 14 statistical package was used to analysis one hundred and twenty (120) questionnaires retrieved from the respondents which represents eightythree (83) per cent of the total questionnaires distributed using multiple regression statistical technique.

\subsection{Model Specification}

Chipa and Womiori (2017) model was adopted but the variables modified as their study failed to take cognizance of risk specificity, which this study considered necessary, with the inclusion of risk management environment, procedure \& policies (EPP). Therefore, the model specification used for the study is stated in equation (3.1) below:

$$
p r f=f(r m t, r m n, e p p, r m e)
$$

Transforming equation 3.1 above into linear relationship, equation 3.2 below was obtained.

$$
p r f=\eta_{0}+\eta_{1} r m t+\eta_{2} r m n+\eta_{3} e p p+\eta_{4} r m e+\mu
$$

Where:

$p r f=$ Profitability of Insurance Firms;

$r m t=$ Risk Mitigation;

$r m n=$ Risk Monitoring;

epp = Risk Management Environment, Procedure \& Policies; and

rme $=$ Risk Measurement

The inclusion of all explanatory variables was informed by extant studies as potent factors influencing profitability of ins urance firms in Nigeria. 
Kehinde I. Olaiya, Kareem A. Arikewuyo, Ashim B. Shogunro, Lateef A. Yunusa.

Effect of Risk Mitigation on Profitability of Insurance Industries in Nigeria

\section{RESULTS}

The summary statistics of the variables considered in the study are shown in Table 1. According to the data, the average performance (prf) as judged by insurance experts is 18.39 , with a standard deviation of 3.6, indicating the risk associated with insurance firm profitability. In addition, the leptokurtic nature of the risk is indicated by a positive kurtosis value of roughly 2.23 in the analysis of the data, while its performance measurement spans between 10 and 25 (representing 25\% and 62.45\%) in terms of minimum and maximum, respectively. Variances across variables range between 16.31 and 17.37 , representing roughly $41 \%$ and $43 \%$ of the total, with variations across variables ranging between.

The summary statistics of the variables considered in the study are shown in Table 1. According to the data, the average performance (prf) as judged by insurance experts is 18.39 , with a standard deviation of 3.6 , indicating the risk associated with insurance firm profitability. In addition, the leptokurtic nature of the risk is indicated by a positive kurtosis value of roughly 2.23 in the analysis of the data, while its performance measurement spans between 10 and 25 (representing 25\% and 62.45\%) in terms of minimum and maximum, respectively. In addition, the average values of all other variables used in this study were found to lie between 16.31 and 17.37 , representing roughly $41 \%$ and $43 \%$, with variability among variables ranging between 4.05 and 4.17, and their positive kurtosis was leptokurtic.

Table 1

Table Showing Descriptive Statistics of Insurance Perception of Workers

\begin{tabular}{|c|c|c|c|c|c|}
\hline & $\boldsymbol{P r f}$ & $\boldsymbol{R} \boldsymbol{m} \boldsymbol{t}$ & $\boldsymbol{R} \boldsymbol{m} \boldsymbol{E}$ & $\boldsymbol{E p p}$ & $\boldsymbol{R} \boldsymbol{m}$ \\
\hline Mean & 18.3917 & 16.3083 & 16.6167 & 17.3250 & 17.3663 \\
\hline Maximum & 25.0000 & 24.0000 & 24.0000 & 25.0000 & 24.0000 \\
\hline Minimum & 10.0000 & 8.0000 & 8.0000 & 6.0000 & 10.0000 \\
\hline Std. Dev. & 4.4406 & 4.0786 & 4.0526 & 4.4555 & 4.1673 \\
\hline Skewness & -0.3845 & -0.0661 & -0.1308 & -0.3452 & -0.2208 \\
\hline Kurtosis & 2.2285 & 2.1325 & 2.1862 & 2.33 & 2.2756 \\
\hline Observation & 120 & 120 & 120 & 120 & 120 \\
\hline
\end{tabular}

Source: Authors' Computation, 2020

Table 2 presents the correlations among the variables of interest. This shows that the correlation between any two explanatory variables is not very high which ruled 
out any presence of Multicollinearity. This is because the correlation figures of the variables are within the acceptable bound (Schober, Boer \& Schwate, 2018).

Table 2

Correlation Matrix of Explained and Explanatory Variables

\begin{tabular}{|c|c|c|c|c|c|}
\hline Variable & Prf & Rmt & Rmn & Epp & Rme \\
\hline Prf & 1.0000 & & & & \\
\hline Rmt & $\begin{array}{c}0.4688^{*} \\
(0.0000)\end{array}$ & 1.0000 & & & \\
\hline Rmn & $\begin{array}{c}0.5099^{*} \\
(0.0000)\end{array}$ & $\begin{array}{c}0.3855^{*} \\
(0.0000)\end{array}$ & 1.0000 & & \\
\hline Epp & $0.4276^{*}$ & $0.5272^{*}$ & $0.3709^{*}$ & 1.0000 & \\
& $(0.0000)$ & $(0.0000)$ & $(0.0000)$ & & \\
\hline Rme & $0.3180^{*}$ & $0.2852^{*}$ & $0.3511^{*}$ & $0.3917^{*}$ & 1.0000 \\
& $(0.0004)$ & $(0.0016)$ & $(0.0001)$ & $(0.0000)$ & \\
\hline
\end{tabular}

Source: Authors' Computation, 2020

Table 3 illustrates the analyses' regression results, indicating a positive significant association between risk mitigation (rmt) and the insurance firm's profitability. At a 1\% level of significance, this means that if risk mitigation is raised by one unit, insurance firm profitability in Nigeria will increase by 0.26 units. Similarly, risk monitoring $(\mathrm{rmn})$ has a favorable and large impact on profitability, implying that the former is crucial to the profitability of insurance companies in Nigeria. Simply put, a unit increases in risk monitoring results with a 0.37 increase in insurance firm profitability in Nigeria. Risk management environment, procedure \& policies (epp), and risk measurement (rme) were found to have both positive and insignificant associations with the profitability of Nigeria's insurance sector. The economic intuition of this study is that risk mitigation $(\mathrm{rmt})$ and risk monitoring $(\mathrm{rmn})$ are major predictors of insurance performance in Nigeria. As a result of their insignificance, these variables have no bearing on insurance profitability in Nigeria. 
Kehinde I. Olaiya, Kareem A. Arikewuyo, Ashim B. Shogunro, Lateef A. Yunusa.

Effect of Risk Mitigation on Profitability of Insurance Industries in Nigeria

Table 3

\section{Regression Result}

\section{Dependent Variable: Profitability}

\begin{tabular}{|c|c|c|c|c|c|}
\hline Variables & Coefficient & Std. Error & $P>t$ & [95\% Conf.] & Interval] \\
\hline \multirow[t]{2}{*}{$\mathrm{Rmt}$} & 0.2605 & 0.0979 & 0.009 & 0.0666 & 0.4543 \\
\hline & $(2.66)$ & 0.0924 & 0.000 & 0.1854 & 0.5514 \\
\hline \multirow[t]{2}{*}{ Rmn } & 0.3684 & 0.0918 & 0.111 & -0.0345 & 0.3292 \\
\hline & $(3.99)$ & 0.0884 & 0.375 & -0.0963 & 0.2538 \\
\hline Epp & $\begin{array}{l}0.1473 \\
(1.60)\end{array}$ & 1.8441 & 0.027 & 0.4673 & 7.7730 \\
\hline Rme & $\begin{array}{l}0.0787 \\
(0.89)\end{array}$ & & & & \\
\hline Constant & $\begin{array}{c}4.1201 \\
(2.23)\end{array}$ & & & & \\
\hline \multicolumn{6}{|l|}{ Diagnostic Tests: } \\
\hline Number of observations & 120 & 120 & 120 & 120 & 120 \\
\hline Adj R-squared & 0.5484 & & & & \\
\hline F-test & $\begin{array}{c}16.91 \\
{[0.0000]}\end{array}$ & & & & \\
\hline $\begin{array}{l}\text { Breusch-Pagan/ } \\
\text { Cook-Weisberg }\end{array}$ & 0.32 & & & & \\
\hline $\operatorname{Chi}^{2}(1)$ & {$[0.5735]$} & & & & \\
\hline Ramsey Reset test & & $\begin{array}{c}1.34 \\
{[0.2662]}\end{array}$ & & & \\
\hline Multicollinearity (Mean VIF) & 1.40 & & & & \\
\hline
\end{tabular}

Source: Authors' Computation, 2020

It is, however, noted from the findings of this study that risk mitigation and monitoring are essentials of insurance profitability in Nigeria and these suggest the need for placing more emphasis on these two variables if insurance companies are keen in improving their profitability in the foreseeable future. On the other hand, risk management environment, procedure \& policies (epp) and risk measurement (rme) should as well be given attention, though not significant, but could assist in driving significant variables. The finding of this study is consistent with the submission of Chipa and Womiori (2017) as risk-inherent variables such as risk mitigation (rmt) and risk monitoring ( $\mathrm{rmn}$ ) significantly influence financial performance of insurance firms which aimed at reducing the financial exposure of insurance firms to risks.

The diagnostic statistic for this study revealed that the $\mathrm{R}^{2}$ is 0.5484 suggests that the dependent variable measured with profitability is explained by 54.84 per 
cent variations in independent variables which signify that the model is of good fit. Furthermore, the F-value of 16.91 is significant at 1 per cent while Breusch-Pagan/ Cook-Weisberg test was conducted to detect the presence of serial autocorrelation and null hypothesis of no serial correlation in the residual of model was accepted. The result of VIF test further confirmed the findings of correlation matrix (see Table 2) of the absence of multicollinearity problem in the variables considered for this study.

\section{CONCLUSION}

Inherent hazards involved with company operations necessitate certain logical tactics for mitigating the risks and anticipating the repercussions of these risks. These tactics can be used to identify, assess, analyze, and monitor risks as well as any associated consequences to keep the project on track to accomplish the business's objectives. These techniques are counterbalanced by attempts to decrease or eliminate associated risks such as time, cost, or complexity. Only by properly evaluating the potential threats or losses can appropriate risk mitigation techniques be established. Risks may be anticipated and managed with the right methods in place. The best risk mitigation approach may lessen the likelihood of a risk, the severity of the outcome, or the organization's exposure to risk. As a result, the findings in table 3 above confirm the preceding conclusions on the impact of risk mitigation on insurance industry profitability in Nigeria. Multiple regressions were used to determine the overall response of each of the constructs, and the study's findings revealed that risk mitigation has a positive and significant relationship with profitability, implying that when risk mitigation increases by one unit, profitability increases by 0.26 at a one per cent level of significance, and risk monitoring also has a positive and significant relationship with profitability. This demonstrates that risk mitigation and risk monitoring are critical for the profitability of the insurance industry in Nigeria, and it suggests that if insurance companies want to improve their profitability in the near future, they should focus more on these two variables. Risk management environment, method \& regulations, and risk measurement; on the other hand, should be given attention as well, as they may aid in driving crucial variables. These will boost their profitability and overall performance in the business, as well as provide them with some protection from any systemic risk that may affect other competitors in the same industry in the long run.

\section{RECOMMENDATIONS}

In order to fulfill their economic and social responsibilities to stakeholders while remaining relevant in the face of stifled industry rivalry, insurance companies should 
Kehinde I. Olaiya, Kareem A. Arikewuyo, Ashim B. Shogunro, Lateef A. Yunusa.

Effect of Risk Mitigation on Profitability of Insurance Industries in Nigeria

incorporate risk mitigation into its policy bank and destination, according to the findings of the study. Insurance regulators should encourage risk identification, assessment, measurement, and control techniques that are compatible with best global practices in order to improve insurance performance. Corporate organizations must clearly communicate their risk appetite and have a good risk culture in order to perform better.

\section{REFERENCES}

1. Abideen, Z.U. and Saleem, S. (2011) Effective advertising and its influence on consumer buying, European Journal of Business and Management, 3(3), 55-65.

2. Ahmed, I. (2016). Effect of capital size on the profitability of listed insurance firms in Nigeria. African Journal of Business Management, 10(5), 109-113.

3. Akotey, J, O. \& Abor, J. (2011). Risk management in the Ghanaian insurance industry. Qualitative Research in Financial Markets, 5(1), 26-42

4. Al-Nimer, M., Abbadi, S. S., Al-Omush, A. \& Ahmed, H. (2021). Risk Management Practices and Firm Performance with a Mediating Role of Business Model Innovation. Observations from Jordan. Journal of Risk and Financial Management14: 113.https://doi.org/10.3390/jrfm14030113

5. Alsallawi, A. M. (2018). The effect of institutional factors on the profitability risk in the insurance companies listed in the Saudi stock market. International Business Research, '11(7), 12-19.

6. Amadei, L. (2016). Why policies and procedures matter. [online] Risk Management. Available at:http://www.rmmagazine.com/2016/11/01/why-policies-andprocedures-matter/[Accessed 27. 10. 2020].

7. Arif, A. \& Showket, A. (2015). Relationship between financial risk and financial performance: an insight of Indian insurance industry. International Journal of Science and Research, 4(11), 1424-1433.

8. Banks, E. (2004). Alternative risk transfer: integrated risk management. through insurance, re-insurance and the capital markets, John Wiley \& Sons Ltd.

9. Chipa, E, M. \& Womiori, G, (2017). Effects of risk management on financial performance of insurance companies in Mombasa County Kenya. Imperial Journal of Interdisciplinary Research (IJIR), 3(5), 259-282. Retrieved 21 $1^{\text {st }}$ April, 2020 from http:// www.onlinejournallll.in

10. Dabari, I. J. \& Saidin S. Z. (2014). A theoretical framework on the level of risk management in the Nigeria banking sector: The moderating effect of top management support. International conference on accounting studies Kuala Lumpur Malaysia.

11. Ebenezer, O. O. \& Omar, W. A. W. (2016). The empirical effects of credit risk on profitability of commercial banks: Evidence from Nigeria. International Journal of 
Science Research (IJSR), 7(2), 14-19.

12. Ennouri, W. (2013). Risk management: New literature review. Polish journal of management studies vol. 8 2013. Pp.288-297.

13. Epron, S. (2019). Emerging Security Threats: Factors and Implications for Nigeria's Socio-Economic Development 2015-2019. Journal of Economics and Development Studies June 2019, Vol. 7, No. 2, pp. 141-149

14. Fali, I., Nyor,T. \& Mustapha, L. O. (2020). Insurance Specific Risk and Profitability: Evidence from Nigerian Insurance Firms. International Journal of Accounting, Finance and Risk Management. Vol. 5, No. 3, 2020, pp. 141-148. doi: 10.11648/j.ijafrm.20200503.13

15. Gatzert, N., Schmit, J. T. \& Kolb, A. (2016). Assessing the risks of insurance reputational risk. Journal of Risk and Insurance vol. 83. No 3 (September 2016) pp. 641-679. Doi: 10.1111/jor.12065. http://www.jstor.org/stable/43998279

16. Huber, C., \& Scheytt, T. (2013). The dispositive of risk management: Reconstructing risk management after the financial crisis. Management Accounting Research, 24(2), 88-99

17. Joosub, T. S. (2006). Risk Management Strategies to maintain Corporate reputation. Dissertation

18. Kripa, D. \& Ajasllari, D. (2016). Factors affecting the profitability of insurance companies in Albania. European Journal of Multidisciplinary Studies, 1(1), 352-360.

19. Laeven, R, J. A. \& Perotti, E. C. (2010). Optimal capital structure for insurance companies. Netspar Discussion Paper No. 11/2010-073 (38).

20. Maher, M. \& Anderson, T. (1999). Corporate governance: Effects on firm performance and economic growth. Organization for Economic Co-operation and Development OECD), 1-51.

21. Mohammed, H. K. \& Knapkova, A. (2016). The impact of total risk management on company's performance. Procedia-Social and Behavioral Science 220, 271-277. Available online at www.sciencedirect.com.

22. Odusanya, I. A., Yinusa, O G. \& Ilo, B. M. (2018) : Determinants of firm profitability in Nigeria: Evidence from dynamic panel models, SPOUDAI - Journal of Economics and Business, ISSN 2241-424X, University of Piraeus, Piraeus, 68(1), 43-58.

23. Olalekan, L. I., Olumide, M. L. \& Irom, I. M. (2018). Financial risk management and the profitability: An empirical evidence from commercial banks in Nigeria. Journal of Management Sciences, 16(2), 117-137.

24. Olalere, O., Ahmed, W. \& Omar, W. A. (2015). The empirical effects of credit risk on profitability of commercial banks: Evidence from Nigeria. International Journal of Science and Research (IJSR), 7(2), 14-19

25. Owolabi, A. O., Oloyede, F. A., Iriyemi, A. B. \& Akinola, A. T. (2017). The 
Kehinde I. Olaiya, Kareem A. Arikewuyo, Ashim B. Shogunro, Lateef A. Yunusa.

Effect of Risk Mitigation on Profitability of Insurance Industries in Nigeria

impact of risk management on the profitability of insurance companies in Nigeria. International Journal of Marketing and Technology, 7(6), 1-26.

26. Owojori, A. A., Akintoye, R. I., \& Adidu, A. F. (2011). The challenge of risk management in Nigerian banks in the post consolidation era. Journal of Accounting and Taxation, 13 (2), 23-31.

27. Rashid, A. \& Kemal, M. U. (2018). Impact of internal (micro) and external (macro) factors on profitability of insurance companies in Pakistan. Journal of Economic Policy Researches Cilt, 5, 35-57.

28. Risk management ISO 31000 (2009). Risk management principles and guidelines.

29. Schmit, J. T. \& Roth, K. (1990). Cost Effectiveness of Risk Management Practices. The Journal of Risk and Insurance, 57(3), 455-470 Available at: https:// www.jstor.org/stable/252842

30. Schober, P., Boer, C \& Schwarte, L. A. (2018). Correlation coefficients: Appropriate use and interpretation. Anesthesia \& Analgesia, 126(5), 1763 - 1768. Retrieved 21/11/2019 from www.anesthesia-analgesia.org.

31. Sebastian, O. \& Duru-uremadu, E. (2017). A review of risk management techniques growth of the Nigeria economy. Agricultural Research \& Technology Open Access Journal, 12(3), 65-68.

32. Sathyamoorthi C. R., Mogotsinyana Mapharing \& Mphoeng Mphoeng \& Mashoko Dzimiri, 2020. „Impact of Financial Risk Management Practices on Financial Performance: Evidence from Commercial Banks in Botswana,“ Applied Finance and Accounting, Redfame publishing, vol. 6(1), pages 25-39, February.

33. Solvency II directive, (2009). Directive 2009/138/EC of the European parliament and of the council of 25 November 2009. On the taking up out pursuit of the business of insurance and reinsurance (solvency II)

34. Thornton, P. H. (2004). Market from culture: Institutional logics and organizational decisions in higher education publishing. Standard University Press

35. Tularam, G. A \& Attili, G. S. (2012). Importance of Risk Analysis and Management - The Case of Australian Real Estate Market. DOI: 10.5772/50669

36. Wenk, D. (2005). risk management and business continuity, overview and perspective". Journal of the Chartered Insurance Institute, 3 (3), 234-246.

37. Yaya, S., Otu, A. \& Labonté, R. Globalisation in the time of COVID-19: repositioning Africa to meet the immediate and remote challenges. Global Health 16, 51 (2020). https://doi.org/10.1186/s12992-020-00581-4

38. Zhara, M. Z. \& Mazreku, I. (2014). Risk management and performance of insurance companies: The case of Kosovo. Academic Journal of Interdisciplinary Studies, 3(2), 293-300. 